\title{
Fish distribution patterns in the White Drin (Drini i Bardhë) river, Kosovo
}

\author{
Linda Grapci-Kotori ${ }^{1}$, Theocharis Vavalidis ${ }^{2,6}$, Dimitris Zogaris ${ }^{3}$, Radek Šanda ${ }^{4}$, Jasna Vukić ${ }^{5}$, \\ Donard Geci ${ }^{1}$, Halil Ibrahimi ${ }^{1}$, Astrit Bilalli ${ }^{1}$ and Stamatis Zogaris ${ }^{6, *}$ \\ ${ }^{1}$ Department of Biology, Faculty of Mathematical and Natural Sciences, University of Prishtina "Mother Theresa", 10000 Prishtina, \\ Republic of Kosovo \\ ${ }^{2}$ Laboratory of Ichthyology, Department of Zoology, School of Biology, Aristotle University of Thessaloniki, 54124 Thessaloniki, Greece \\ ${ }^{3}$ Department of Ichthyology and Aquatic Environment, School of Agricultural Sciences, University of Thessaly, 38446 Volos, Greece \\ ${ }^{4}$ National Museum, Department of Zoology, 11579 Prague, Czech Republic \\ 5 Department of Ecology, Charles University, 12844 Prague, Czech Republic \\ ${ }^{6}$ Institute of Marine Biological Resources and Inland Waters, Hellenic Centre for Marine Research, Anavissos, 19013 Attiki, Greece
}

Received: 31 January 2020 / Accepted: 27 May 2020

\begin{abstract}
Fish assemblages and their distributions in the western Balkan rivers have rarely been investigated. This study provides initial insights into the spatial patterns of fish distributions in the mainstem of the White Drin in Kosovo. Sampling primarily utilized back-pack electrofishing at 11 sites along the river's entire main stem, recording 21 species. Identification of most fish species was confirmed through DNA barcode analyses; two yet unnamed species are present and some taxonomic problems were discovered. The abundance of non-native species was low (5.9\% of the catch) but seven of the eight nonnatives have established populations. A longitudinal fish zonation pattern was described for the first time in this river; fish assemblages in an upstream-to-downstream gradient were characterized by a decrease of cold-water species (salmonids, minnows) and an increase of large-river cyprinids and non-native species. Multivariate ordination and network analyses demarcate preliminary fish assemblage types and specific environmental and anthropogenic pressure attributes are shown to influence assemblage structure. Natural assemblage patterns may be locally disrupted by anthropogenic pressures such as pollution and hydromorphological disturbances, however most sites show semi-natural features and conditions. Recommendations for conservation and further research are provided.
\end{abstract}

Keywords: rivers / fish zones / Balkans / endemic species / taxonomy

Résumé - Distribution des poissons dans la rivière White Drin (Drini i Bardhë), Kosovo. Les assemblages de poissons et leur répartition dans les rivières des Balkans occidentaux ont rarement fait l'objet d'études. Cette étude donne un premier aperçu des schémas spatiaux de distribution des poissons dans le cours principal de la White Drin au Kosovo. L'échantillonnage a principalement été réalisé par pêche électrique à dos sur 11 sites le long du cours principal de la rivière, avec collecte de 21 espèces. L'identification de la plupart des espèces de poissons a été confirmée par des analyses de codes-barres ADN; deux espèces non encore identifiées sont présentes et certains problèmes taxonomiques ont été découverts. L'abondance des espèces non indigènes était faible (5,9\% des prises), mais sept des huit espèces non indigènes ont établi des populations. Un modèle de zonage longitudinal des poissons a été décrit pour la première fois dans cette rivière; les assemblages de poissons dans un gradient d'amont en aval ont été caractérisés par une diminution des espèces d'eau froide (salmonidés, vairons) et une augmentation des cyprinidés de grande rivière et des espèces non indigènes. Des analyses d'ordination et de réseau multivariées délimitent les types préliminaires d'assemblages de poissons et il est démontré que des indices de pression environnementaux et anthropiques spécifiques influencent la structure des assemblages. Les modèles d'assemblage naturels peuvent être localement perturbés par des pressions anthropiques telles que la pollution et les perturbations hydromorphologiques, mais la plupart des sites présentent des

\footnotetext{
*Corresponding author: zogaris@hcmr.gr; zogaris@gmail.com
} 
caractéristiques et des conditions semi-naturelles. Des recommandations pour la conservation et des recherches supplémentaires sont fournies.

Mots clés : rivières / zones piscicoles / Balkans / espèces endémiques / taxonomie

\section{Introduction}

Knowledge of fish assemblages provide a unique view into river biota, framing a reference for monitoring river health and conservation. River fish distributions are not randomly ordered, they show spatial assemblage structure; specific conditions and anthropogenic pressures affect them (Matthews, 1998; Sutela et al., 2010). In many jurisdictions, such as in the European Union, governments are obliged to classify their surface water bodies on the basis of a typology that is relevant to natural species assemblage structure (EU, 2003). Fish are therefore important in classifying aquatic systems both at the longitudinal river scale and regional scale and this has important implications for policy-relevant monitoring and water management (Aarts and Nienhuis, 2003; Zogaris et al., 2009). Classifications of fish assemblages are also critically important in biodiversity conservation, since individual fish assemblage or community units may warrant conservation actions (Angermeier and Schlosser, 1995; Angermeier and Winston, 1999). Fish assemblage classifications are also dependent on a knowledge of fish taxonomy, an active research area in recent years, especially in globally important biodiversity regions such as the Balkans (Kottelat and Freyhof 2007; Vavalidis et al., 2019). In this study, we focus on a poorly-explored hotspot for fish diversity in Europe, a tributary of the Drin river in the western Balkans.

Since the break-up of Yugoslavia in the early 1990s and serious civil strife and war in the region the study of river biodiversity has been sidelined for decades (Skoulikidis et al., 2009). The Ohrid-Drin-Skadar river system (hereafter ODS) being the largest river basin $\left(19,686 \mathrm{~km}^{2}\right)$ in the Southeast Adriatic Freshwater Ecoregion is an understudied biodiversity hotspot (Freyhof and Brooks 2011; Darwall et al., 2014; Ibrahimi et al., 2014; WWF/TNC 2019). We focus on one of the two main tributary branches of this river system, the White Drin (Drini i Bardhë) in Kosovo. Basic knowledge of fish assemblage distributions are poorly documented (GrapciKotori et al., 2010; Wenke, 2017) and unusually for a European river, there are still serious problems with fish taxonomy in the ODS as a whole (for example, Marková et al., 2010; Palandačić et al., 2015). However, there is active interest in applying biomonitoring and bioassessment to European Union standards (Grapci-Kotori et al., 2013). This study provides insights for fish distribution spatial structure in the main stem of the White Drin, focusing on species-level taxonomy and fish community assemblage classification, in an effort to help build baselines for biodiversity and river health monitoring.

\section{Study area and methods}

\subsection{River catchment}

The ODS has two main tributaries: the White Drin, arising from Northwestern Kosovo and the Black Drin from Lake
Ohrid (North Macedonia, Albania) which is also fed by subterranean waters from Lake Prespa (North Macedonia, Albania, Greece). The basin discharges in the Adriatic near the Albania-Montenegro border. Much of the system within Albania and North Macedonia has been artificially impounded by five high hydroelectric dams (Skoulikidis et al., 2009; Spirkovski et al., 2017). The free-flowing part of the White Drin (Drini i Bardhë) is $109 \mathrm{~km}$ long and comprises a catchment of $4340 \mathrm{~km}^{2}$; all within the Republic of Kosovo. It has the highest river water flow in Kosovo and is the second most significant sub-basin of the Drin (Grapci-Kotori et al., 2010). Nearly the entire White Drin valley is located on an upland plateau between 300 to $450 \mathrm{~m}$. a.s.l. and is nearly surrounded by high alpine mountains with a continental temperate climate. This spring-fed river hosts extensive cold and cool-water conditions that are rare in low-relief topography conditions in the Mediterranean river catchments. These river conditions are influenced by a rather long period of winter freezing and a strong spring freshet flooding. Although river flow drops in the summer, it does not decrease markedly such as in most other Mediterranean rivers; the entire mainstem and major tributaries sustain perennial flow conditions. The White Drin catchment crosses the Kosovo-Albanian border at the lowest point $(280 \mathrm{~m}$. a.s.1.), near Vermicë, where the river condition is already affected by the permanent impounding due to the Albanian hydroelectric-dam of Fierza on the main stem of the Drin.

\subsection{Sampling}

Fish sampling was conducted at 11 sites along the longitudinal axis of the main stem of the White Drin during low river flow (July 2019); while three sites sampled in summer had been previously sampled in winter as well (December 2017). The sampling network covered representative reaches along a $95 \mathrm{~km}$ distance within the entire area of the flow of the river's main stem in Kosovo, from just a few hundred meters downstream of the White Drin springs to near the Kosovo-Albania border. The sites were distributed as evenly as possible and with a representative cover of all available natural habitats (Fig. 1).

Sampling consisted primarily of electrofishing, following approaches used through the European Union Water Framework Directive (EU WFD) monitoring protocols (CEN, 2003) which has been applied in several areas of the Balkans (IMBRIW, 2013; Zogaris et al., 2018). Sampling was located at a river stretch usually demarcated by physical boundary features to minimize fish escape during electrofishing (e.g. riffle areas, changes in instream habitats, natural or artificial barriers). A high-quality battery-powered back-pack electrofishing unit was used (Smith Root 24L -DC pulsed, $1.5 \mathrm{KW}$, 35-100 Hz, $\max 980 \mathrm{~V}$.). At each site, a single pass of at least a $100 \mathrm{~m}$ river stretch was completed, without using a stop-net (average fishing-time was $71 \mathrm{~min}$ ). At all sites, fish were collected in large water-filled buckets and processed on shore. 


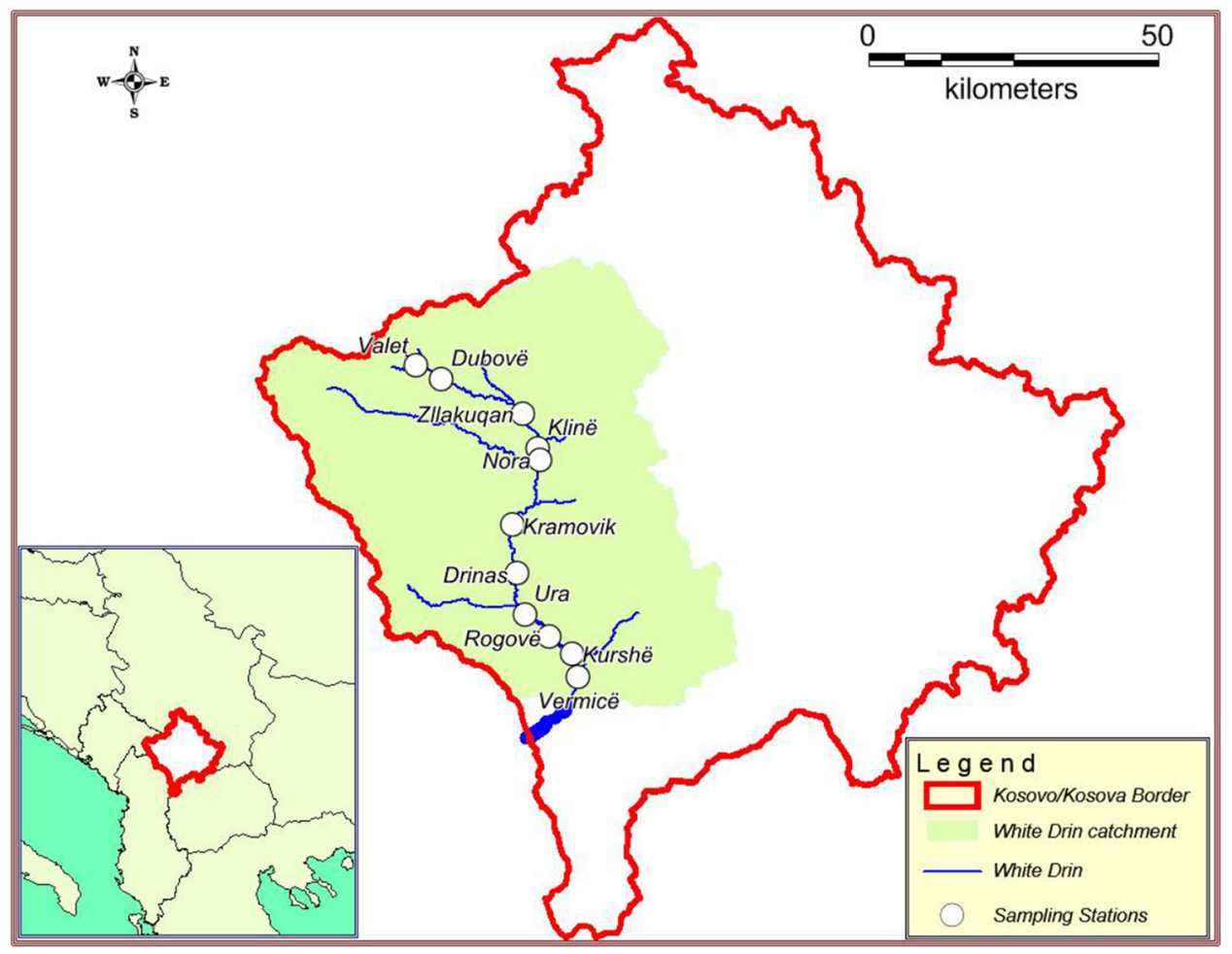

Fig. 1. Free-flowing White Drin catchment in Kosovo and the 11 surveyed sites along its main stem. The name of the nearest village or main place-name is provided (see Table 2 for equivalent sample names used in analyses).

Fish were identified to species or genus level in the field; counted, measured to size-class intervals and most were released back to the river (following a technique described in Dußling et al., 2004; IMBRIW, 2013). Selected specimens where collected for lab inspection (see below) and photography in a portable aquarium. All fish were rapidly inspected for significant DELT anomalies such as external deformities, eroded fins, lesions and tumours (Sanders et al., 1999), however only severely unhealthy fish were recorded as having DELTs.

In all sampling sessions, the same operator electrofished and the same or similar field crews participated in order to ensure that effort was consistent among sites. The field crew consisted of one electrofisher operator (who also usually carried the back-pack generator and a dip-net) and at least three other participants with dip-nets. At the three lower river reaches where river depth exceeded waist-high in the majority of the channel, back-pack electrofishing was supplemented by a combination of fishing methods to adequately sample the assemblage. In two sites electrofishing through wading was supplemented by electrofising by boat (using the same generator), while cast net samples and/or overnight gill-nets were also used at another three sites (see Tab. 2). The gill nets used were two simple and relatively short nylon nets $(7 \mathrm{~m}$ long and $1.5 \mathrm{~m}$ high; $4 \mathrm{~cm}$ mesh-size); this size of mesh is aimed to catch relatively large-sized fish, which may escape electrofishing in deeper waters. The gill-nets were tied to tree branches and set for about 8 hours (at night); they were used only at the deepest water site (site: Vermice19). The cast net was a local fishermen's costume-made cast net; it was used by an experienced local fishermen for about one hour (sites: Ura19, Rogove19). These supplementary tools and methods provided increased effort which was commensurate with the much deeper water and wider wetted-width river conditions in the lower river sites.

\subsection{Species identifications}

Species nomenclature follows Kottelat and Freyhof (2007) with particular additions promoted in recent publications (Zupančič et al., 2010; Marková et al., 2010; Palandačić et al., 2015, 2017). To verify field identifications a subset of 107 selected specimens of 12 species were screened in the laboratory through DNA barcoding analyses. After the specimens were sacrificed using a high dose of clove-oil a piece of fin tissue was extracted and stored in 96\% ethanol for subsequent molecular analyses (specimens are housed in the HCMR Fish Museum and the Prague Museum). Mitochondrial DNA markers were applied in species identification. The DNA extraction, PCR reaction mix and PCR product purification follow Šanda et al. (2008). For most species cytochrome b was applied due to availability of the best comparative data, and the above amplification protocol. For the genus Gobio, cytochrome c oxidase subunit I (COI) was more appropriate for comparison, and PCR protocol and primers followed Geiger et al. (2014). In the case of the genus Salmo a control region was used, following laboratory procedure described in Duftner et al. (2003). Sequencing was carried out by the Macrogen Service Centre Europe (Amsterdam, Netherlands) using the amplification primers. Sequences were aligned manually and revised in BioEdit (v.7.0.9). Sequence comparison with published data was 
conducted by BLAST (https://blast.ncbi.nlm.nih.gov/Blast.cgi). Newly recorded haplotypes were deposited in GenBank (see Supplementary Table 1).

\subsection{Environmental data collection}

As defined in the IMBRIW protocol (2013), environmental and habitat parameters were recorded and calculated at each study site. These include classic physicochemical parameters, i.e. conductivity $\left(\mu \mathrm{S} \mathrm{cm}^{-1}\right.$, Cond), dissolved oxygen $\left(\mathrm{mg} \mathrm{L}^{-1}, \mathrm{DO}\right), \mathrm{pH}$ and water temperature $\left({ }^{\circ} \mathrm{C}, \mathrm{T}\right)$. In addition, habitat parameters, i.e. visual on-site estimations include: mean wetted width (m, WW), mean and maximum depth $(\mathrm{cm}, D)$, stream velocity (categories of mean flow speed), substrate coarseness, as well as relative in-stream habitats, estimated in percent cover at the site (pools, glides, runs, rifles, rapids) and vegetation cover (scaled cover of helophytes and aquatic macrophytes). In the analyses some of the data were combined to genaralize conditions i.e. substrate types were defined as "course" (rock, boulders, cobbles) and "fine" (pebble, gravel, sand, silt). Finally, spatial and geographical parameters, i.e. distance from source (m, Dist) and elevation $(\mathrm{m}, \mathrm{El})$ were calculated from recent satellite images and GIS application.

\subsection{Anthropogenic pressures data}

Anthropogenic degradation of the sampled river sites was assessed based on the identification of anthropogenic pressures known to influence and impact fish (see Degerman et al., 2007; Schinegger et al., 2012, for criteria and relevant references). In order to provide a rapid assessment of the level of anthropogenic impact (degradation) of each site we chose selected pressures for which we could rapidly gather on-site knowledge as has been done in other Balkan countries (Zogaris et al., 2018). Twelve anthropogenic pressure categories were assessed based on our on-site observations (recorded in the sampling field protocol), published pressure assessments (i.e. available recent chemical measurements) and remotely sensed data (recent Google Earth images). The assessed parameters were scored by the authors based on best available information, established pressure-impact criteria and expert judgement. The quality condition of each site based on the severity of each pressure is given on a scale of 1 to 5 following the EU WFD standard (i.e. $1=$ high, 2 =good, 3 = moderate, $4=$ poor, $5=$ bad). Some pressures were assessed at a five-class scale (i.e. $1=$ least impacted to $5=$ highly impacted) others in three point classes (i.e. 1, 3, 5 or 1, 2, 5); assessment scoring has lower degrees of certainty in some pressure types so the class scale is reduced to three classes. The following twelve pressure parameters were assessed as follows (increment score measures applied given in parentheses): Channel modification (1-5); Instream habitat modification (1, 3, 5); Artificial embankment (1-5); Riparian vegetation modification (1-5); Barrier upstream (1,2,3); Barrier downstream $(1,3,5)$; Barrier basin $(1,3,5)$; Water abstraction $(1,3,5)$; Hydropeaking $(1,2,5)$; Hydrological modification $(1,3,5)$, Impoundment (1-5); Pollution $(1,2,5)$. Finally, a preliminary degradation index was calculated for each site by simply summing the scores and dividing by the number of pressures assessed.

\subsection{Data analysis}

Abundance data during electrofishing runs (number of fish per single run) were converted to area densities (i.e. individuals $* 100 \mathrm{~m}^{-2}$ ) to provide a proxy for catch-per-unit effort (CPUE) where the unit of effort is the extent of area surveyed. The surface area sampled at each site was estimated from its geometrical characteristics on-site (careful visual measurement and estimation of reach length and crosssectional width in the field; and through recent Google Earth images). In the four sampling events where supplementary gears were used we considered species CPUE data from all gear types to be comparable in terms of potential sampling bias.

Assessment of the importance of the different physicochemical, habitat and spatial variables was conducted by applying multivariate statistics. In all analyses samples used assessed fish density per site; $\log (x+1)$ transformation was used for the analyses in fish densities, environmental/habitat and pressure variables. In order to detect differences between sampling sites in terms of environmental/habitat and pressure characteristics PCA analyses was applied for each set of variables. Before PCA we tested possible correlation between variables with Spearman's rank correlation. To explore the spatial pattern of fish distribution, to identify areas with similar fish assemblages and to compare these assemblages among areas, a non-parametric multidimensional scaling (MDS) was performed using fish densities (individuals $* 100 \mathrm{~m}^{-2}$ ). MDS portray the compositional differences between sampled sites in an ordination that provides a visual indication of how similar sites are to one another. For all the above analyses the Primer 6 statistical package was used (Clarke and Gorley, 2006).

We also investigated possible gradation changes in fish communities using bipartite networks. In such networks each site is linked only with the species it contains, and each species only with sites where they occurred. Through this kind of classification grouping, species identities are not lost, as in a resemblance matrix (Leroy et al., 2019), giving the opportunity to detect modules, which represent aggregated sets of species (Dormann and Strauss, 2014). The "Bipartite" package (Dormann et al., 2008) in R (R Development Core Team, 2017) was employed in this analysis.

To further examine fish responses to environmentalhabitat and pressure variables the CANOCO procedure was used. (CANOCO 4.5 for Windows; Ter Braak and Smilauer, 2002). By applying DCA, the length of gradient in the first axis was calculated at 3.2, indicating that the Standard Deviation of species turnover is not too high (i.e. less than 4) so we analyzed the data by Redundancy Analysis (RDA). Prior to RDA analysis, the Monte Carlo test was used, under 499 permutations, to specify the statistical significant habitat environmental and pressure variables. To avoid variables that are correlated and thus have no unique contribution to the regression, variables only with inflation factor $<20$ were used.

\section{Results}

As shown in Table 1, 21 fish taxa were recorded from a total of 3301 specimens during the summer (2019) and 507 
Table 1. List of all species (1); distinction of provenance and taxonomy (i.e. Native or non-native/ certainty of identification; with "+" checked using DNA molecular analyses) (2); Endemicity, showing region and non-native status: A: Alien, T: translocated non-native (3); Total number collected (4), Frequency of occurrence at sites - F.O. (5), length-class range collected in total (6); and, total percent deformations documented of $\%$ collected (7).

\begin{tabular}{|c|c|c|c|c|c|c|}
\hline $\begin{array}{l}1 \\
\text { Species } \\
\text { (Family) }\end{array}$ & $\begin{array}{l}2 \\
\text { Provenance/ } \\
\text { Taxonomy }\end{array}$ & $\begin{array}{l}3 \\
\text { Endemicity }\end{array}$ & $\begin{array}{l}4 \\
\text { Total } \\
\text { number }\end{array}$ & $\begin{array}{l}5 \\
\text { F.O. }\end{array}$ & $\begin{array}{l}6 \\
\text { Length } \\
\text { Class } \\
\text { Range }\end{array}$ & $\begin{array}{l}7 \\
\text { Total DELTS } \\
\text { (\% of total } \\
\text { caught })\end{array}$ \\
\hline $\begin{array}{l}\text { Alburnoides ohridanus } \\
\text { (Leuciscidae) }\end{array}$ & Native/Certain + & $\begin{array}{l}\text { Northern Southeast } \\
\text { Adriatic }\end{array}$ & 985 & 11 & $<5,11-15$ & 0.9 \\
\hline Alburnus scoranza (Leuciscidae) & Native/Certain + & Southeast Adriatic & 589 & 12 & $<5,16-20$ & 0.2 \\
\hline Barbatula sturanyi (Nemacheilidae) & Native/Certain + & ODS Basin & 64 & 8 & $<5,11-15$ & 0 \\
\hline Barbus sp. (Cyprinidae) & Native/Certain + & ODS Basin & 204 & 11 & $<5,26-30$ & 3.4 \\
\hline Carassius gibelio (Cyprinidae) & Non-native/Uncertain & Non-Native A & 4 & 2 & $6-10,21-25$ & 25 \\
\hline Chondrostoma ohridanus (Leuciscidae) & Native/Certain + & Southeast Adriatic & 47 & 6 & $6-10,26-30$ & 0 \\
\hline Cobitis ohridana (Cobitidae) & Native/Uncertain & Southeast Adriatic & 1 & 1 & $6-10$ & 0 \\
\hline Cyprinus carpio (Cyprinidae) & Non-native/Certain & Non-Native $\mathrm{T}$ & 1 & 1 & $21-25$ & 0 \\
\hline $\begin{array}{l}\text { Eudontomyzon stankokaramani } \\
\text { (Petromyzontidae) }\end{array}$ & Native/Certain & ODS Basin & 11 & 2 & $11-15,16-20$ & 0 \\
\hline Gobio skadarensis /ohridanus (Gobionidae) & Native/Uncertain + & Southeast Adriatic & 125 & 9 & $<5,11-15$ & 5.6 \\
\hline Oncorhynchus mykiss (Salmonidae) & Non-native/Certain & Non-Native A & 3 & 2 & $21-25,26-30$ & 0 \\
\hline Pachychilon pictum (Leuciscidae) & Native/Certain + & Southeast Adriatic & 557 & 11 & $<5,16-20$ & 2.3 \\
\hline Perca fluviatilis (Percidae) & Non-native/Certain & Non-Native $\mathrm{T}$ & 18 & 3 & $<5,11-15$ & 0 \\
\hline Phoxinus sp. (Leuciscidae) & Native/Certain + & ODS Basin & 720 & 6 & $<5,6-10$ & 0 \\
\hline Pseudorasbora parva (Gobionidae) & Non-native/Certain & Non-Native A & 37 & 6 & $<5,6-10$ & 0 \\
\hline Rhodeus amarus (Acheilognathidae) & Non-native/Certain + & Non-Native $\mathrm{T}$ & 118 & 9 & $<5,6-10$ & 0 \\
\hline Sabanejewia balcanica (Cobitidae) & Non-native/Certain + & Non-Native $\mathrm{T}$ & 28 & 7 & $<5,11-15$ & 0 \\
\hline Salaria fluviatilis (Blenniidae) & Native /Certain & Peri-Mediterranean & 3 & 2 & $6-10,11-15$ & 0 \\
\hline Salmo farioides (Salmonidae) & Native/Uncertain + & Western Balkans & 92 & 8 & $6-10,31-35$ & 3.3 \\
\hline Sander lucioperca (Percidae) & Non-native/Certain & Non-Native $\mathrm{T}$ & 13 & 2 & $6-10,26-30$ & 0 \\
\hline Squalius platyceps (Leuciscidae) & Native/Certain + & Southeast Adriatic & 205 & 12 & $<5,51-55$ & 2.9 \\
\hline
\end{tabular}

specimens in the winter expedition (2017). The species represent 21 genera and 10 families (in Cypriniform fish we follow the families of Schönhuth et al., 2018). Of the 13 native species, 10 are range-restricted almost exclusively within the Southeast Adriatic Ecoregion. This represents a very high endemicity, approximately $77 \%$ of native fish species being unique to this ecoregion (ecoregion boundaries follow Abell et al., 2008). Five taxa are considered endemic to the ODS or at least the northern part of the Southeast Adriatic Ecoregion (i.e. species of Phoxinus, Barbus, Barbatula, Alburnoides, Eudontomyzon). Another five are restricted within the wider Southeast Adriatic Ecoregion (i.e.: species of Cobitis, Pachychilon, Alburnus, Chondrostoma and probably Gobio).

Eight species are non-native, this includes five species which are "translocated" from nearby ecoregions. All but one non-native species (Oncorhynchus mykiss) show signs of being established with self-reproducing populations. Non-native species still have a comparatively low effect on the fish assemblage, comprising only $5.9 \%$ of the total catch; Rhodeus amarus being the only non-native species exceeding 100 individuals within the total catch.

The most abundant species were Alburnoides ohridanus, Phoxinus sp., Alburnus scoranza, Pachychilon pictum and Squalius platyceps (in descending order of abundance); accounting for $79.9 \%$ of all individuals collected. The most widespread species (frequency of occurrence $>80 \%$ samples) were: Squalius platyceps, Alburnus scoranza, Pachychilon pictum, Barbus sp. and Alburnoides ohridanus. The most range-restricted species (occurrence $<20 \%$ samples) were: Sander lucioperca, Salaria fluviatilis, Oncorhynchus mykiss, Eudontomyzon stankokaramani, Carassius gibelio, Cyprinus carpio and Cobitis ohridana. Table 2 provides a summary of basic environmental and catch data for each sample in descending order (sampled sites ordered from an upstream to downstream gradient as in the map in Fig. 1).

\subsection{Fish taxonomy and fish assemblage characterization}

19 of the 21 taxa are identified to valid species, though in some cases the identification is tentative; four species being of uncertain taxonomic status (Tab. 1, see discussion for details). DNA barcoding considerably helped in species identification. The two species that remain unnamed belong to genera Phoxinus and Barbus, though both are identified to known, but yet undescribed evolutionary lineages.

MDS ordination shows a progression of grouping from upstream to downstream, with distinctive cold water sites located upstream. The three sites sampled in summer and winter maintained similar assemblage structure (Fig. 2). 
Table 2. List of all samples with important parameters: Site sample name and in parentheses the nearest toponym as in Map (Fig.1) (1); geographic coordinates at centre of sampling site (2); Sampling method (1: electrofishing, 2:boat electrofishing, 3: cast-net, 4: gill-net) (3); Distance from the source (spring of the White Drin) in meters (4); Elevation a.s.l. in meters (5); Degradation score: sum of scores divided by 12 (total number of anthropogenic pressures assessed) (6); Native species number (7); Non-native species number (8); Number of individuals collected (9); Estimated fish density at site density (individuals* $100 \mathrm{~m}^{-2}$ ) (10); length-class ranges of all fish species collected (11); Number of serious deformities, lesions, or tumors (DELTS) on the fishes (12).

\begin{tabular}{|c|c|c|c|c|c|c|c|c|c|c|c|}
\hline $\begin{array}{l}1 \\
\text { Site name } \\
\text { (and nearest } \\
\text { toponym) }\end{array}$ & $\begin{array}{l}2 \\
\text { Geographic } \\
\text { Location }\end{array}$ & $\begin{array}{l}3 \\
\text { Sampling } \\
\text { Method }\end{array}$ & $\begin{array}{l}4 \\
\text { Distance } \\
\text { from } \\
\text { source }\end{array}$ & $\begin{array}{l}5 \\
\text { Elevation }\end{array}$ & $\begin{array}{l}6 \\
\text { Degradation } \\
\text { index }\end{array}$ & $\begin{array}{l}7 \\
\text { Native }\end{array}$ & $\begin{array}{l}8 \\
\text { Non- } \\
\text { native }\end{array}$ & $\begin{array}{l}9 \\
\text { Number of } \\
\text { individuals }\end{array}$ & $\begin{array}{l}10 \\
\text { Fish } \\
\text { density }\end{array}$ & $\begin{array}{l}11 \\
\text { Length- } \\
\text { class } \\
\text { range }\end{array}$ & $\begin{array}{l}12 \\
\text { DELTS }\end{array}$ \\
\hline $\begin{array}{l}\text { 1. Valet19 } \\
\text { (Valet) }\end{array}$ & $\begin{array}{l}42.736638 \\
20.311722\end{array}$ & 1 & 618 & 531 & 2.91 & 1 & 1 & 34 & 7.55 & $6-10,26-30$ & 0 \\
\hline $\begin{array}{l}\text { 2.Dubove19 } \\
\text { (Dubovë) }\end{array}$ & $\begin{array}{l}42.716944 \\
20.364166\end{array}$ & 1 & 6881 & 469 & 2.41 & 3 & 1 & 383 & 212.77 & $<5,31-35$ & 0 \\
\hline $\begin{array}{l}\text { 3.Zllak19 } \\
\text { (Zllakoqan) }\end{array}$ & $\begin{array}{l}42.662222 \\
20.535752\end{array}$ & 1 & 25972 & 394 & 2.66 & 8 & 0 & 405 & 225.00 & $<5,21-25$ & 0 \\
\hline $\begin{array}{l}\text { 3.Zllak17 } \\
\text { (Zllakoqan) }\end{array}$ & $\begin{array}{l}42.662222 \\
20.535752\end{array}$ & 1 & 25972 & 394 & 2.66 & 8 & 0 & 267 & 70.26 & $<5,11-15$ & 2 \\
\hline $\begin{array}{l}\text { 4.Kline19 } \\
\text { (Klinë) }\end{array}$ & $\begin{array}{l}42.609305 \\
20.567000\end{array}$ & 1 & 34860 & 373 & 3.75 & 9 & 1 & 224 & 124.44 & $<5,21-25$ & 4 \\
\hline $\begin{array}{l}\text { 4.Kline } 17 \\
\text { (Klinë) }\end{array}$ & $\begin{array}{l}42.609305 \\
20.567000\end{array}$ & 1 & 34860 & 373 & 3.75 & 8 & 2 & 100 & 76.92 & $<5,26-30$ & 2 \\
\hline $\begin{array}{l}\text { 5.Nora19 } \\
\text { (Nora) }\end{array}$ & $\begin{array}{l}42.591552 \\
20.572052\end{array}$ & 1 & 38384 & 369 & 3.16 & 9 & 1 & 131 & 43.67 & $<5,21-25$ & 4 \\
\hline $\begin{array}{l}\text { 5.Nora } 17 \\
\text { (Nora) }\end{array}$ & $\begin{array}{l}42.591552 \\
20.572052\end{array}$ & 1 & 38384 & 369 & 3.16 & 8 & 1 & 139 & 75.14 & $<5,11-15$ & 4 \\
\hline $\begin{array}{l}\text { 6.Kramovik19 } \\
\text { (Kramovik) }\end{array}$ & $\begin{array}{l}42.491055 \\
20.513444\end{array}$ & 1 & 54722 & 347 & 3.91 & 7 & 3 & 746 & 165.78 & $<5,21-25$ & 3 \\
\hline $\begin{array}{l}\text { 7.Drinas } 19 \\
\text { (Drinas) }\end{array}$ & $\begin{array}{l}42.416222 \\
20.523222\end{array}$ & 1 & 65267 & 330 & 3.25 & 8 & 4 & 304 & 86.86 & $<5,26-30$ & 4 \\
\hline $\begin{array}{l}\text { 8.Ura19 } \\
\text { (Ura) }\end{array}$ & $\begin{array}{l}42.353555 \\
20.539583\end{array}$ & $1,2,3$ & 74855 & 334 & 2.41 & 9 & 2 & 350 & 175.00 & $<5,21-25$ & 2 \\
\hline $\begin{array}{l}\text { 9.Rogove19 } \\
\text { (Rogovë) }\end{array}$ & $\begin{array}{l}42.318166 \\
20.591527\end{array}$ & 1,3 & 82039 & 308 & 2.33 & 7 & 4 & 279 & 111.60 & $<5,51-55$ & 1 \\
\hline $\begin{array}{l}\text { 10.Kursha19 } \\
\text { (Kurshë) }\end{array}$ & $\begin{array}{l}42.292583 \\
20.639277\end{array}$ & 1 & 87453 & 301 & 2.50 & 7 & 3 & 218 & 72.67 & $<5,16-20$ & 1 \\
\hline $\begin{array}{l}\text { 11.Vermice19 } \\
\text { (Vermicë) }\end{array}$ & $\begin{array}{l}42.256375 \\
20.651088\end{array}$ & $1,2,4$ & 94151 & 293 & 3.25 & 6 & 7 & 245 & 98.00 & $<5,31-35$ & 2 \\
\hline
\end{tabular}
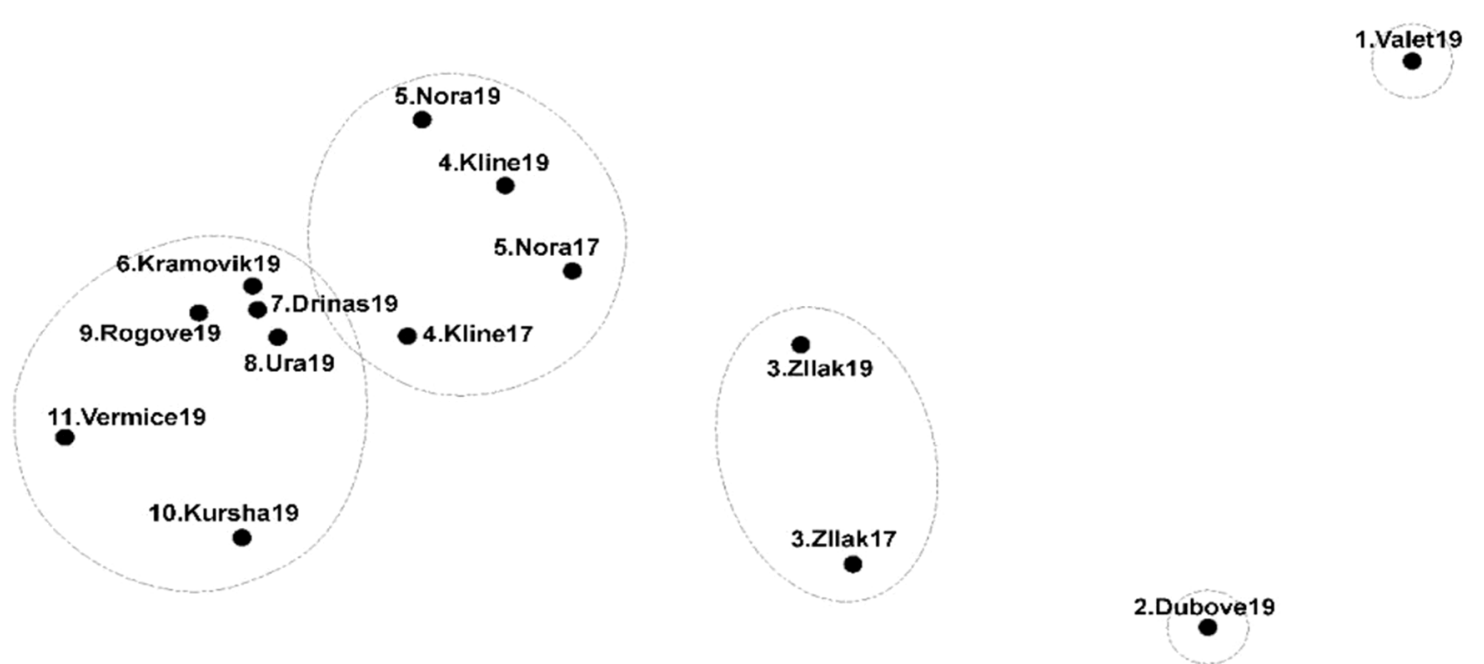

Fig. 2. MDS ordination for White Drin samples based on fish densities (individuals* $100 \mathrm{~m}^{-2}$ ). Sites to the right half of the ordination are in coldwater conditions. Kline and Nora sites are in a cool-warm water transition that is also seasonally heavily polluted. The left hand grouping includes warm water assemblages. 


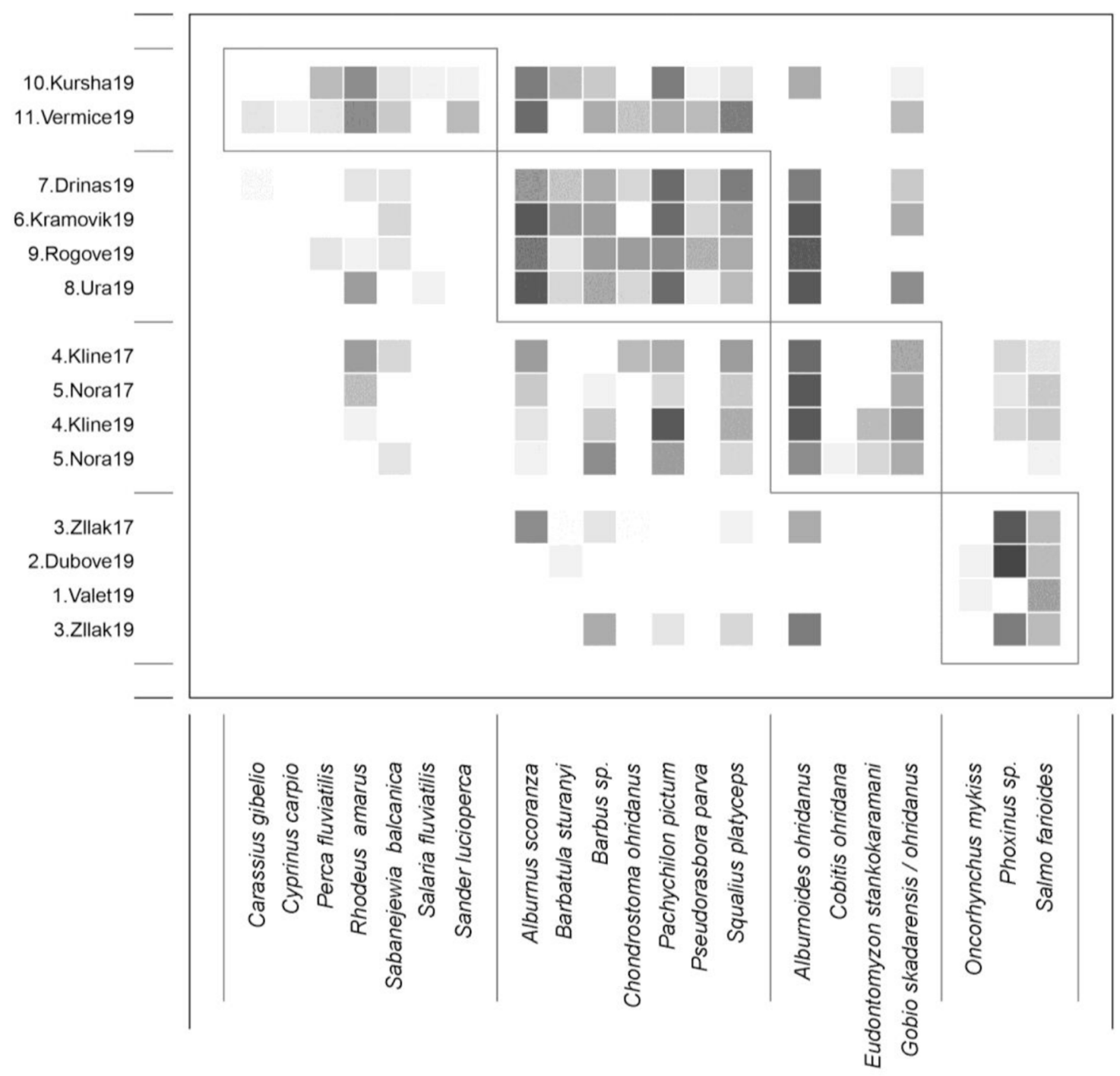

Fig. 3. Assemblage level modules of White Drin River fishes in bipartite network analyses. Darker shades in each square indicate higher population density values.

Bipartite network analyses suggests the existence of four preliminary fish assemblage types (Fig. 3). The downstream segments had the highest species richness and diversity per site. Three cold-water species occurred exclusively in the upstream cold water reaches, while several species, including most non-natives were found exclusively in the most downstream warm water sections respectively.

\subsection{Fish responses to environmental, habitat and pressure parameters}

PCA for environmental and habitat variables identifies potential parameters that characterize site conditions (Fig. 4). Spearman's correlation shows that distance from source was highly correlated with altitude $(-0.996)$ and fine substrate with coarse substrate $(-0.987)$. From the analyses distance from source and fine substrate were excluded.

RDA analyses for environmental and habitat variables (Fig. 5a) show that hydromorphological and habitat parameters are important in influencing fish assemblages. In terms of environmental and habitat variables fish species partition primarily between cold-water and the large-river species (Fig. 5a). Temperature, a key physico-chemical parameter, may have an overriding importance, but other notable parameters are shown to include the overall size and dominant morphology of the river, indicated by wetted width and the presence of slow-flowing habitats and fine sediment conditions (i.e. areas where helophytes develop). Species-variables relation was explained by $87.1 \%$ in the fourth axis although only water temperature was statistical significant $(p=0.002)$ according to Monte Carlo test; the model was not statistically significant both in the 1 st $(F$-ratio $=3.341 ; p$-value $=0.2800)$ and in all axes $(F$-ratio $=2.107 ; p$-value $=0.0680)$.

In the ordination of anthropogenic pressures (Fig. 5b), certain pressures are identified as noteworthy and may play a role in fish community dynamics, prominent ones including barriers (especially downstream barriers), hydrograph modification (through water diversions) and pollution. Anthropogenic hydromorphological modifications are probably important (channelization, downstream barriers, impounding 


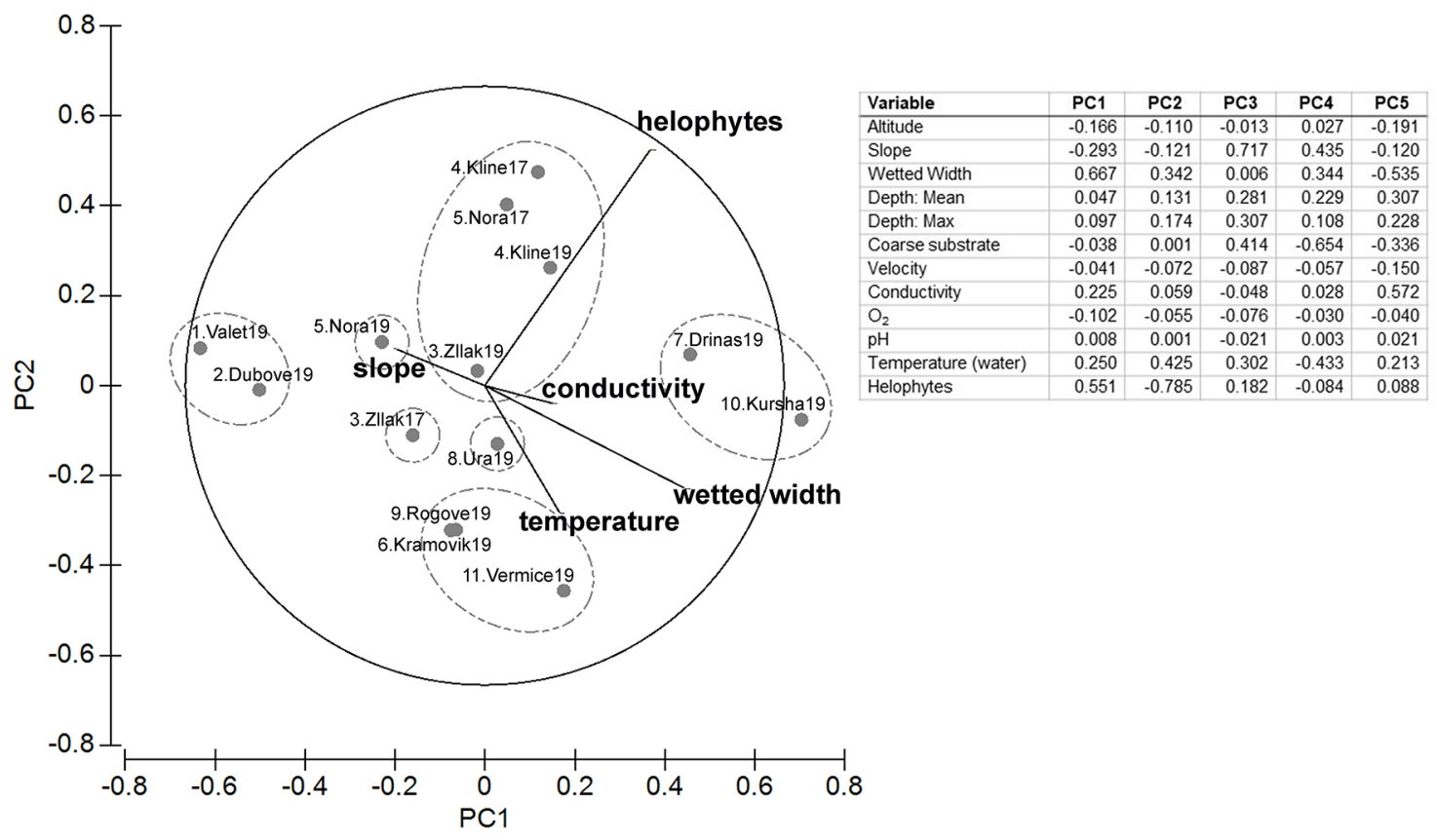

Fig. 4. PCA graph for environmental and habitat variables. Only variables with scores $>0.2$ in at least one of the two axes are presented in the ordination. PCA values presented in table.
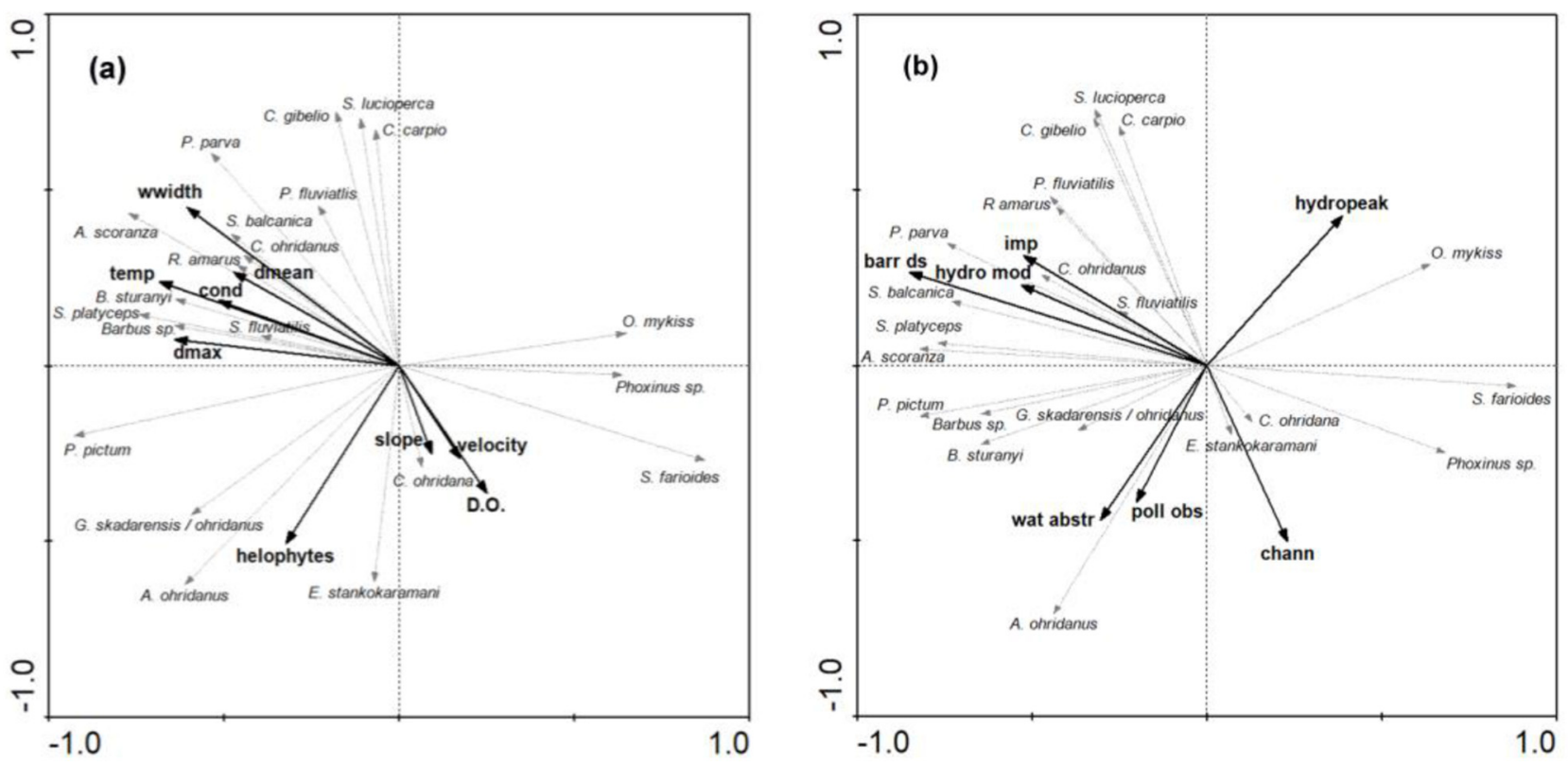

Fig. 5. RDA-analyses for a) environmental and habitat variables, and b) anthropogenic pressures. Abbreviated names refer to the following variables: cond: conductivity $(\mu \mathrm{S} / \mathrm{cm})$, dmean: mean depth $(\mathrm{m})$, dmax: maximum depth $(\mathrm{m})$, temp: water temperature $\left({ }^{\circ} \mathrm{C}\right)$, wwidth: wetted width (m), helophytes: \% cover of helophytes, slope: Slope (\%), velocity: average river velocity (average m/sec classes), D.O.: Dissolved oxygen (mg/l). hydropeak: Water level hydropeaking (below hydroelectric power plants), barr ds: Artificial barriers Upstream, barr ds: Artificial barriers downstream, chann: River channelization, imp: Impoundment due to barriers and dams, hydro mod: Hydrograph modification, wat abstr: Water abstraction, poll obs: Pollution observed visually on-site.

of waters due to barriers and hydrological modification) however it is not possible to interpret the influence of some pressure types without monitoring data (i.e. the effects of pollution or local habitat degradation from river quarrying, for example). Species-variables relation was explained by
93.3\% in fourth axis and it was statistically significant both in 1 st $(F$-ratio $=4.5 ; p$-value $=0.02)$ and in all other axes $(F$-ratio $=2,228 ; p$-value $=0.02)$. According to Monte Carlo test statistically significant variables are river channelization $(p=0.042)$ and barriers in the basin (downstream) $(p=0.002)$. 


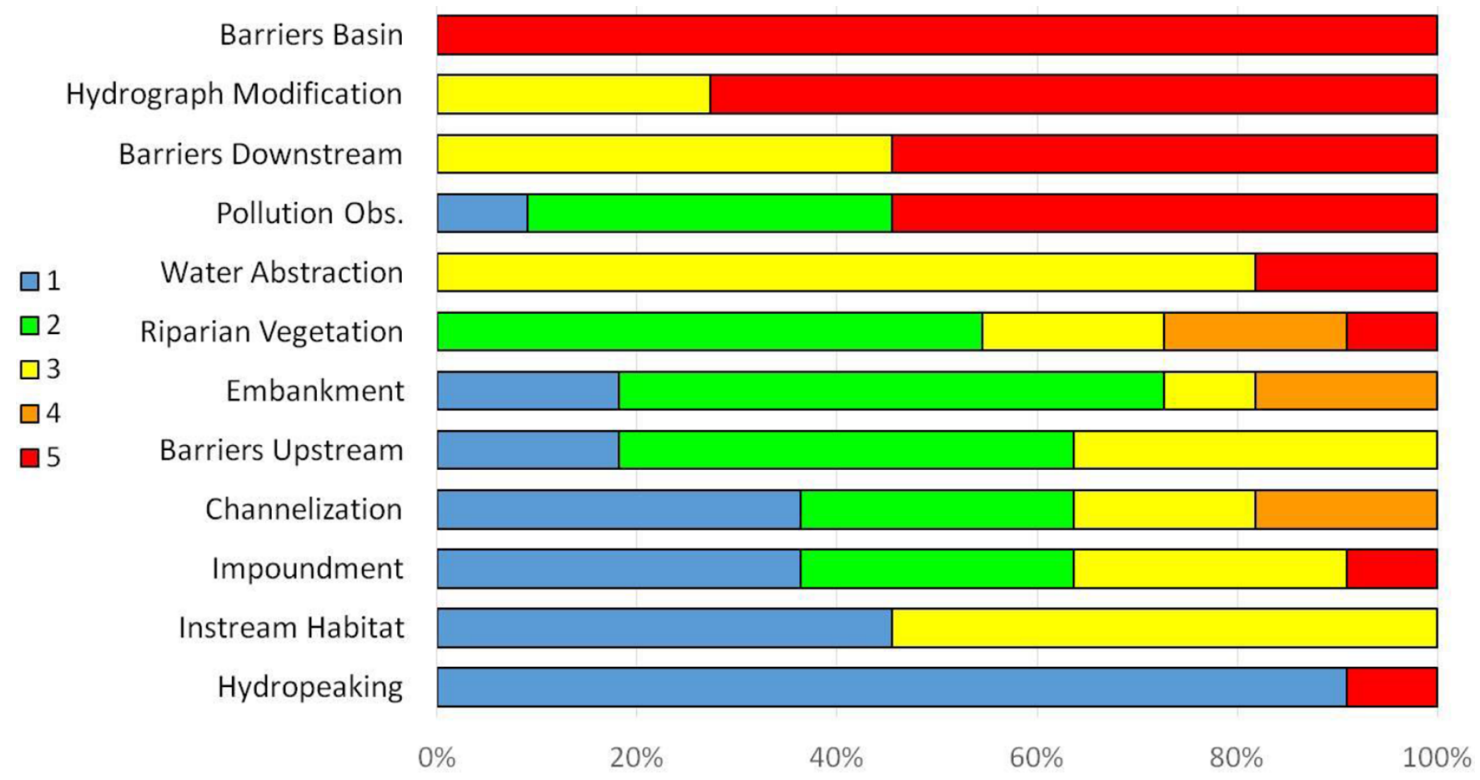

Fig. 6. Prevalence of the degree of degradation caused by anthropogenic pressures for fish at the 11 surveyed sites (assessed on-site and through available recent measurements and remote sensing). The degree of degradation is given by a five-point scale (from least impacted to severely degraded condition; i.e. $1=$ high, $2=$ good, $3=$ moderate, $4=$ poor, $5=$ bad).

In terms of assessed pressures at the site-scale (Fig. 6), most river reaches that were inspected show a low or moderate degree of influence from selected pressures known to influence fish communities. The most widespread and severe recorded pressures were: basin-scale barriers to fish movement (major dams in the basin), seasonal hydrological modification due to river diversions (thus affecting the river's natural hydrograph) and pollution. Other pressure types show low or slight modification scores at most sites.

\section{Discussion}

\subsection{Taxonomic implications}

The western Balkans still have serious gaps and instability in freshwater fish taxonomy (Bogutskaya and Ahnelt, 2019; Vavalidis et al., 2019). Several fish genera in the ODS are represented by two species and exact distribution patterns in the basin are poorly documented (Simonović, 2001; GrapciKotori, 2010; Wenke, 2017). Furthermore, the potential for misidentifications due to human-mediated translocations is a serious problem in the region (Koutsikos et al. 2012, Piria et al., 2018, Koutsikos et al., 2019a; Vukić et al., 2019). Considering these facts, species identification, the most important starting point for any conservation-relevant analysis, is in many taxa difficult. In such cases, DNA barcoding is a useful tool. We interpret our most important findings here.

In this study we retain two of our identifications to genus level (Phoxinus and Barbus). The genus Phoxinus recently underwent enormous taxonomic changes (Palandačić et al., 2017; Vucić et al., 2018; Corral-Lou et al., 2019). Eight different evolutionary lineages were identified by Palandačić et al. (2015), two of which occur in the ODS. Phoxinus karsticus inhabits the Lake Skadar catchment (and part of the Neretva drainage), whereas a yet unnamed Phoxinus species was reported from Lake Ohrid and its vicinity (Palandačić et al., 2015, 2017). All 15 genetically analysed specimens from the White Drin belong to the native "Phoxinus sp. 5" of Palandačić et al. (2017). Moreover, two species of Barbus were also reported from the ODS by Marková et al. (2010): presumably the introduced Barbus balcanicus from a small river near the confluence of White and Black Drin (in Albania), and a yet undescribed species from several localities in the ODS, though none of them from the White Drin. All six genetically analysed specimens from White Drin belong to the native undescribed Barbus of Marková et al. (2010), obviously widespread throughout the ODS.

Two species of the genus Gobio are also reported from the ODS: G. ohridanus and G. skadarensis, formerly presumed endemic to Lake Ohrid and the Lake Skadar area, respectively (Kottelat and Freyhof, 2007). However, the taxonomy of this genus in this area remains unresolved. The published data, all molecular (Šanda et al., 2005; Mendel et al., 2008; Geiger et al., 2014) are not fully congruent, since other populations from the Southeast Adriatic Ecoregion are genetically very closely related. Gobio species are also frequently translocated by humans (Aparicio et al., 2013; Bianco, 2014; Jelić et al., 2016) and other Gobio species are present in the neighbouring ecoregions (Geiger et al., 2014). Our sequences of all twelve specimens analysed genetically from the White Drin are most similar to G. ohridanus sequences from Lake Ohrid (Geiger et al., 2014). The majority of the specimens bear identical haplotypes as those in the above mentioned publication, and in case of yet not reported haplotypes the maximum difference is $0.15 \%$ (see Suppl. 1), so we may tentatively consider the White Drin population as being closest to G. ohridanus. On the other hand, the next genetically most similar species, G. skadarensis, differs only $0.61-0.77 \%$. The observed values of genetic differentiation are very small and further research is needed to solve this issue; therefore we refer to our Gobio specimens as 
G. ohridanus/skadarensis. This provisional nomenclature is used in an attempt to provide an unbiased operational name solely for this publication.

An unexpected situation was detected in the genus Squalius; the ODS is assumed to host S. platyceps (Zupančič et al., 2010). Of the nine specimens analysed in our study, seven were identified as $S$. platyceps. However, one specimen bears mtDNA of $S$. prespensis and one of $S$. cephalus. It is not clear, if these species are present in the White Drin (respectively in the ODS), and what is their status. In many Squalius populations ancient genetic introgression was detected, so the mtDNA could be misleading in species identification (Perea et al., 2016; Sousa-Santos et al., 2019; Buj et al., 2020). Furthermore, introductions of Squalius were also reported from the western Balkans (Jelić et al., 2016). Without further detailed study, it is not possible to decide if more species occur sympatrically in the White Drin or if the observed pattern only reflects introgressive hybridisation, either ancient, or recent, resulting from human-mediated introduction.

A taxononomically difficult group in the area are the trout (Salmo), where several species are reported from the ODS (Kottelat and Freyhof, 2007). The most widespread species is expected to be $S$. farioides, but other species are present in the neighbouring drainages and the introductions of non-native Salmo species are well documented in the Balkans (Piria et al., 2018, Koutsikos et al., 2019b). The mitochondrial data can provide only limited information since the supposed specieslevel taxa bear similar or even identical haplotypes (Geiger et al., 2014). All ten analysed Salmo specimens in our study belong clearly to the Adriatic evolutionary lineages and we tentatively identify them as native $S$. farioides.

Even presumably widespread and common species pose risks of identification errors in this region. The taxonomy of Chondrostoma in the ODS has been unclear for a long time since two species were reported from the drainage; C. scoranza considered endemic to Lake Skadar and presumed extinct (Kottelat and Freyhof, 2007) and C. nasus (Elvira, 1987). Geiger et al., (2014) demonstrate that $C$. ohridanus inhabits the entire ODS. All six genetically investigated specimens from the White Drin are native $C$. ohridanus. Moreover, a single species of Alburnus (A. scoranza) was reported from the ODS (Kottelat and Freyhof, 2007) while several morphologically similar species occur in the surrounding basins (Buj et al., 2010) with reports of translocations throughout the Mediterranean catchments (e.g. Bianco, 2014; Jelić et al., 2016; SousaSantos et al., 2018). In our case all 20 genetically investigated specimens from the White Drin are native A. scoranza. Similarly, a single species of Alburnoides (A. ohridanus) is reported from the ODS, formerly presumed to be endemic to Lake Ohrid (Kottelat and Freyhof, 2007). However, Stierandová et al. (2016) demonstrate this species is more widespread in the ODS. Several morphologically similar species occur in the surrounding basins, some not yet described (Stierandová et al., 2016; Barbieri et al., 2017) and a recent translocation was reported from the western Balkans (Vukić et al., 2019). All 15 genetically investigated specimens inspected from White Drin are native $A$. ohridanus. Finally, two Barbatula species were reported from the ODS, $B$. sturanyi from Lake Ohrid and the Black Drin, and $B$. zetensis from the Lake Skadar basin (Kottelat and Freyhof, 2007). Another species, B. barbatula, occurs in the Danube and Vardar basins (Šedivá et al., 2008) and anthropogenic translocations have been documented (Tutman et al., 2017). A single specimen analysed genetically from the White Drin in this study is confirmed as native B. sturanyi. Also, Cobitis, a rare loach in the system, was morphologically identified as Cobitis ohridana, a widespread species in the Southeast Adriatic ecoregion (Šanda et al., 2008) but DNA was not screened in the few specimens caught. It is known that another Cobitis species of unclear origin (possibly hybridogenetic) occurs in the ODS (Perdices et al., 2008, Sanda et al., 2008) so care is needed in confirming this species' distribution (Buj et al., 2015).

The identity of some of the introduced species is sometimes not easy to determine. For example, two species of Rhodeus, both morphologically highly similar (Kottelat and Freyhof, 2007), occur in the neighboring drainages. One of them, $R$. amarus was identified and classified as introduced in ODS (Bartáková et al., 2019). All ten genetically analyzed specimens from the White Drin are also R. amarus, suggesting this introduced species is widespread in the ODS. A single specimen of Sabanejewia balcanica, a widespread species in the Danube and some north Aegean rivers, showing considerable intraspecific genetic diversity (Marešová et al., 2011) was also DNA barcoded, and confirms the morphological identification. Because this species was never documented from the ODS in the past (Šorić, 1990, 1992; Rakaj et al., 1995; Bohlen et al., 2003; Sanda et al., 2008), we consider it recently introduced by humans. Finally, the identification of some species remains tentative since DNA analysis was not completed. The field identification of Carassius gibelio is provisional since the morphologically highly similar species C. auratus (feral form) has been detected genetically in Lakes Ohrid and Skadar and C. lansdorfii in several nearby drainages (Kalous et al., 2013). Carassius gibelio is tentatively identified here based on morphological characters since genetic analyses was not conducted.

The results show clearly, that the White Drin basin is more similar to Lake Ohrid and the Black Drin rather than to the Lake Skadar sub-drainage. In all cases, where we were able to genetically compare the species pairs reported from the ODS, the White Drin populations were identified as the species previously reported only from Lake Ohrid and the Black Drin.

\subsection{Preliminary fish assemblage patterns and limitations of the study}

This study provides the first attempt to implement a standarized fish assemblage sampling method along the entire main-stem of the White Drin upstream of the Albanian dam impounded area. The initiative was effective in sampling nearly all known fish taxa in the river (Simonovic, 2001; Grapci-Kotori et al., 2010) and providing relative abundance data along with site accounts of environmental parameters and selected anthropogenic pressures. Our quantitative bipartite network analysis identified four modules that may reflect an equal number of geographically discrete fish assemblage types in the river's main stem; this was broadly corroborated by the MDS ordination analysis. The distributional pattern resembles the classic fish zonation (Huet, 1959) in the upper part of the river but the assemblages are dominated by regional endemics not found in central European rivers. As expected, fish species 
richness in the White Drin exhibited a gradual downstream increase; a discrete cold-water assemblage is prevalent in the upstream cold water sections. Further research into a fishbased typology of the White Drin is required in order to confirm and map the assemblage pattern (Vila-Gispert et al., 2002), to consider the effects of the tributary network (Hitt and Angermeier 2011) and to build a biotic typology for fish-based bioassessment (Aarts and Nienhuis, 2003) in this part of the ODS.

We acknowledge some limitations in our study with regards to the precision of the fish abundance data, assessed environmental parameters and anthropogenic pressure variables. To define and validate fish community assemblage types, we should take care when utilizing quantitative fine-scale data since relative abundance parameters in the samples may be influenced by several factors, such as seasonal changes and sampling bias. Fish sampling is not easily kept consistent in such varied main-stem river conditions. Locally supplementing back-pack electrofishing with gill-net, boat-based electrofishing and cast net data was deemed essential in areas such as the three non-wadable sites in the lower part of the river. Applying additional sampling gears may perform better than electrofishing in assessing both river health and biodiversity in medium and large-river conditions (Zajicek and Wolter, 2018; Zajicek et al., 2018). Finally, a potential confounding factor that is hard to interpret may also be overfishing pressure by amateur fishers. Our work therefore represents an exploratory snap-shot towards fish assemblage classification; more surveys and monitoring are required to confirm and further interpret these results.

In terms of assessing anthropogenic pressures, our survey follows a rapid assessment procedure that provides a standard framework that is widely used (Schineggar et al., 2012); however it is not a holistic diagnosis and cannot cover all forms of disturbance that may influence fish assemblages. Some aspects, such as pollution, are poorly registered in this study since the issue of pollution is poorly monitored in Kosovo's rivers (Waschak, 2012); and this should be ameliorated in future pressure-impact analyses.

Through our attempts at identifying important anthropogenic pressures, we show that the majority of the investigated sites were not severely influenced by anthropogenic structural changes to major habitats (i.e. instream habitat degradation, channelization, upstream barriers, embankments and riparian vegetation degradation gave good assessment scores at most sites). In fact, the in-stream and riparian habitat conditions in most sites had a wide and wooded riparian zone and were in rather good condition of ecosystem integrity. In future studies, in order to explore ecological quality in a holistic sense, we highly recommend the use of riparian and landscape scale assessment applications (Wiens, 2002; Fausch et al., 2002; Townsend et al., 2003) and propose that supplementary methods to assess pressures at the riparian and landscape scale should be incorporated in the analyses, to complement on-site field-based assessments (e.g. Chatzinikolaou et al., 2011; Dimitriou et al., 2012; Vlami et al., 2019).

The fish communities of the White Drin seem to retain a semi-natural pattern (i.e. low alien species abundance) primarily influenced by natural longitudinal gradient river changes. However, the creation of longitudinal barriers (high dams) at the wider river basin scale has had serious baseline affects. Some fish populations have been extirpated; these include natural eel (Anguilla anguilla) populations and other migratory fishes, perhaps also including Alosa fallax (Spirkovski et al., 2017). Other fishes have also vanished due to the dams in the main Drin river downstream of the Kosovo Border (e.g. Acipenser naccarii, Acipenser sturio, Petromyzon marinus) (Knezevic, 1981; Rakaj, 1995; Simonovic 2001). Historical research would help to explore if these or other large-river migratory fishes once reached the White Drin catchment.

\subsection{Conservation implications}

Fish assemblage research helps to identify unmet conservation needs. Fish are sensitive to interruptions in the river longitudinal continuum (such as dams); and, as long-lived species, they indicate degradation that may have taken place in the past (e.g. through assessments with respect to size, age, reproduction success and fish health condition) (Schmutz et al., 2000; Sutela et al., 2010; Benejam et al., 2010). The White Drin faces pressures and threats that reflect on its fish assemblages; however, since historic fish assemblage data are unavailable, we are faced with the difficultly of interpreting conditions that are influenced both by natural and anthropogenic changes at multiple scales (Schmutz et al., 2000). We tentatively point to certain insights of conservation and research interest from our study so far:

- Non-native fish translocation is a very serious biodiversity threat, especially when it originates from neighbouring river basins. Three neighbouring freshwater ecoregions with very different ichthyofaunas exist within Kosovo's territory (Abell et al., 2008); this poses very serious risks for human-mediated river basin nonnative fish contamination. In bordering ecoregions we must be especially aware of same-genera "sister species" introduction; their establishment and hybridization with native species may represent an irreversible anthropogenic impact to biodiversity. The spread of many alien and translocated fishes in the Balkans is usually associated with fishery practices (stocking), poorlycontrolled fishing practices (bait-fish translocations) and by dam creation (Shumka et al., 2008; Gashi et al., 2016; Piria et al., 2018; Koutsikos et al., 2019a). Prevention of un-regulated fish transport, strict fisheries enforcement and genetic monitoring (Leese et al., 2018) is an imperative for conservation.

- Pollution is potentially a serious problem for fishes of the White Drin; but there is little chemical monitoring data available to effectively interpret how it affects fishes. Urban sewage waters are commonly discharged un-treated into the rivers, since few sewage treatment plants are in operation (Wenke, 2017). Locally, pollution may have an overriding affect on the fish community and this was presumed to be the situation in the river's mid-section; at the two peri-urban sites near Kline. At these locations, the observed heavy benthic siltation was also probably anthropogenic and may also negatively influence fish (Wood and Armitage, 1997; Sutela et al., 2010). At these and other sites, we also documented fish-health problems by inspection of "DELT" anomalies; these are known to often be associated with severely polluted conditions 
(Sanders et al., 1999). Since river-caught fish are widely consumed by local populations we must stress that this problem also represents a potential human health risk.

- Although hydromorphological conditions are in fairly good status in many parts of the White Drin, water abstraction structures and the influence of dams is a widespread pressure and growing threat. Since many of the Drin's fishes are migratory or undergo seasonal movements (Simonovic, 2001), barriers to movement are a severe problem even if these are located far from the main-stem, in the river's tributaries. It is well documented that a large number of small hydroelectric plants are currently being planned and being built in the White Drin's tributaries (Bajçinovci et al., 2019). The main stem of the river and important reaches in its tributaries should be protected from future proposed dams or barriers. The problem of barriers to fish movement may be more severe than pollution for fishes; however, this issue is poorly studied in Kosovo.

- Over-fishing and illegal fishing are evident in Kosovo and are widespread in the Western Balkans (e.g. Milošević and Talevski, 2015). In our survey, we found that fish were generally small-sized (indicating a scarcity of larger longer-lived specimens) and illegal gill-netting and castnet fishing was widely observed. Standardized quantitative fish monitoring is required to better interpret the effects of this pressure.

Finally some of the sites in both the upper part of the mainstem (i.e. cold-water sites with the endemic Phoxinus minnow assemblages) and the lower reaches that are not yet influenced by impoundments (e.g. Ura, Rogovë, and Kurshë sites) represent outstanding examples of natural and semi-natural river corridor habitats in this river and they should be further studied and considered for conservation within new protected areas. For a complete conservation plan, including an assessment of possible climate change effects on the biota (Reid et al., 2019), fish surveys and monitoring using a standardized methodology should be established on the White Drin and all its tributaries.

\section{Supplementary Material}

\section{Supplementary Table 1.}

The Supplementary Material is available at https://www.kmaejournal.org/10.1051/kmae/2020020/olm.

Acknowledgements. Funding for this study was provided by the Ministry of Education Sciences and Technology of Kosovo., ref. nr. 5210, 17/12/2018. The field work-electrofishing was carried out with permit of the Ministry of Agriculture nr. 2689/3. JV was supported by the institutional resources of the Ministry of Education, Youth, and Sports of the Czech Republic. RS by the Ministry of Culture of the Czech Republic (DKRVO 2019-2023/6.V.b National Museum, 00023272). The authors are grateful for editorial assistance by Elena Oikonomou and Vassiliki Vlami and the field assistance provided by Rinor Berisha, Lis Kotori, Egzona Pepaj and Erlinda Sallauka.

\section{References}

Aarts BGW, Nienhuis PH. 2003. Fish zonations and guilds as the basis for assessment of ecological integrity of large rivers. Hydrobiologia 500: 157-178.

Abell R, Thieme ML, Revenga C, Bryer M, Kottelat M, Bogutskaya N, Coad B, Mandrak N, Contreras-Balderas S, Bussing W, Stiassny M.L.J., Skelton P, Allen GR, Unmack P, Naseka A, Ng R, Sindorf N, Robertson J, Armijo E, Higgins JV, Heibel TJ, Wikramanayake E, Olson D, Lopez HL, Reis RE, Lundberg JG, Sabaj-Pırez MH, Petry P. 2008. Freshwater ecoregions of the world: A new map of biogeographic units for freshwater biodiversity conservation. BioScience 58: 403-414.

Aparicio E, Carmona-Catot G, Kottelat M, Perea S, Doadrio I. 2013. Identification of Gobio populations in the northeastern Iberian Peninsula: first record of the non-native Languedoc gudgeon Gobio occitaniae (Teleostei, Cyprinidae). Bioinvasions Rec 2: 163-166.

Bajçinovci BQ, Gashi M, Aliu V, Bajçinovci B, Bajçinovci U. 2019. Rivers in the name of sources for the Renewable Energy. JOSHA 6: $1-7$.

Barbieri R, Vukić J, Šanda R, Kapakos Y, Zogaris S. 2017. Alburnoides economoui, a new species of spirlin from Central Greece and redescription of Alburnoides thessalicus (Actinopterygii, Cyprinidae). Biologia 72: 1075-1088.

Bartáková V, Bryja J, Šanda R, Bektas Y, Stefanov T, Choleva L, Smitha C, Reichard M. 2019. High cryptic diversity of bitterling fish in the southern West Palearctic. Mol Phylogenet Evol 133: $1-11$.

Benejam L, Benito J, García-Berthou E. 2010. Decreases in condition and fecundity of freshwater fishes in a highly polluted reservoir. Water Air Soil Poll 210: 231-242.

Bianco PG. 2014. An update on the status of native and exotic freshwater fishes of Italy. $J$ Appl Ichthyol 30: 62-77.

Bogutskaya NG, Ahnelt H. 2019. New data on the western Balkan leuciscids Alburnoides and Alburnus (Teleostei, Leuciscidae) from the Vjosa River, Albania. ZooKeys 870: 101-115.

Bohlen J, Šlechtová V, Šanda R, Kalous L, Freyhof J, Vukić J, Mrdak D. 2003. Cobitis ohridana and Barbatula zetensis in the River Morača Basin, Montenegro: distribution, habitat, population structure and conservation needs. Folia Biol (Krakow) 51: $147-153$.

Buj I, Vukić J, Šanda R, Perea S, Ćaleta M, Marčić Z, Bogut I, Povž M, Mrakovčić M. 2010. Morphological comparison of bleaks (Alburnus, Cyprinidae) from the Adriatic Basin with the description of a new species. Folia Zool 59: 129-141.

Buj I, Ćaleta M, Marčić Z, Šanda R, Vukić J, Mrakovčić M. 2015. Different histories, different destinies: impact of evolutionary history and population genetic structure on extinction risk of the Adriatic spined loaches (genus Cobitis; Cypriniformes, Actinopterygii). PLoS One 10: e0131580.

Buj I, Marčić Z, Čavlović K, Ćaleta M, Tutman P, Zanella D, Duplić A, Raguž L, Ivić L, Horvatić S, Mustafić P. 2020. Multilocus phylogenetic analysis helps untangling the taxonomic puzzle of chubs (genus Squalius; Cypriniformes, Actinopteri) in the Adriatic basin in Croatia and Bosnia and Herzegovina. Zool J Linn Soc in press.

CEN. 2003. Water Quality - Sampling of Fish With Electricity CEN/ TC 230, Ref. No. EN 14011:2003 E. (16 pp.).

Chatzinikolaou G, Ntemiri K, Zogaris S. 2011. River riparian zone assessment using a rapid site-based index in Greece. Fresenius Environ Bull 20: 296-302. 
Clarke KR, Gorley RN. 2006. PRIMER v6: User Manual/Tutorial (Plymouth Routines in Multivariate Ecological Research). PRIMER-E, Plymouth.

Corral-Lou A, Perea S, Aparicio E, Doadrio I. 2019. Phylogeography and species delineation of the genus Phoxinus Rafinesque, 1820 (Actinopterygii: Leuciscidae) in the Iberian Peninsula. J Zool Syst Evol Res 57: 926-941.

Darwall W, Carrizo S, Numa C, Barrios V, Freyhof J, Smith K. 2014. Freshwater Key Biodiversity Areas in the Mediterranean Basin Hotspot: Informing Species Conservation and Development Planning in Freshwater Ecosystems. Cambridge, UK/Malaga, Spain: IUCN.

Degerman E, Beier U, Breine J, Melcher A, Quataert P, Rogers C, Roset N, Simoens I. 2007. Classification and assessment of degradation in European running waters. Fish Manag Ecol 14: 417-426.

Dimitriou E, Mentzafou A, Zogaris S, Tzortziou M, Gritzalis K, Karaouzas I, Nikolaidis Ch. 2012. Assessing the environmental status and identifying the dominant pressures of a transboundary river catchment, to facilitate efficient management and mitigation practices. Environ Earth Sci 66: 1839-1852.

Dormann CF, Strauss R. 2014. A method for detecting modules in quantitative bipartite networks. Methods Ecol Evol 5: 90-98.

Dormann CF, Gruber B, Fründ J, 2008. Introducing the bipartite package: Analysing ecological networks. R News 8: 8-11.

Duftner N, Weiss S, Medgyesy N, Sturmbauer C. 2003. Enhanced phylogeographic information about Austrian brown trout populations derived from complete mitochondrial control region sequences. J Fish Biol 62: 427-435.

Dußling U, Bischoff A, Haberbosch R, Hoffmann A, Klinger H, Wolter C, Wysujack K, Berg R. 2004. The fish-based assessment system - description of the German approach. In: Steinberg C, Calmano W, Klapper H, Wilken RD. (Eds.), Handbuch angewandte Limnologie. Ecomed-Verlag, Landsberg, pp.27-38.

Elvira B. 1987. Taxonomic revision of the genus Chondrostoma Agassiz, 1835 (Pisces, Cyprinidae). Cybium 11: 111-140.

EU. 2003. Common implementation strategy for the Water Framework Directive 2000/60/EC. Guidance Document No. 10, River and Lakes - Typology, Reference Conditions and Classification Systems. Luxembourg: Office for Official Publications of the European Communities, $87 \mathrm{p}$.

Fausch KD, Torgersen CE, Baxter CV, Li HW. 2002. Landscapes to riverscapes: Bridging the gap between research and conservation of stream fishes. BioScience 52: 483-498.

Freyhof J, Brooks E. 2011. European Red List of Freshwater Fishes. Luxembourg: Publications office of the European Union.

Gashi A, Shabani E, Grapsi-Kotori LG, Bislimi K, Maxhuni Q, Ibrahimi H. 2016. Contribution to the knowledge of fish fauna of Kosovo with a special note on some invasive species. Turk J Zool 40: 64-72.

Geiger MF, Herder F, Monaghan MT, Almada V, Barbieri R, Bariche M, Berrebi P, Bohlen J, Casal-Lopez M, Delmastro GB, Denys GPJ, Dettai A, Doadrio I, Kalogianni E, Kärst H, Kottelat M, Kovačić M, Laporte M, Lorenzoni M, Marčić Z, Özulug M, Perdices A, Perea S, Persat H, Porcelotti S, Puzzi C, Robalo J, Šanda R, Schneider M, Šlechtová V, Stumboudi M, Walter S, Freyhof J. 2014. Spatial heterogeneity in the Mediterranean Biodiversity Hotspot affects barcoding accuracy of its freshwater fishes. Mol Ecol Resour 14: 1210-1221.

Grapci-Kotori LG, Zhushi Etemi F, Sahiti H, Gashi A, Škrijelj R, Ibrahimi H. 2010. The ichthyofauna of Drini i Bardhe River (Kosovo). Ribarstvo 68: 149-158.
Grapci-Kotori LG, Zhushi-Etemi F, Ibrahimi H, Sahiti H, Gashi A, Rexhepi A. 2013. Testing of EFI index in context of small mountain streams in Kosovo quality assessment. Int J Sci Res Publ 3: 1-5.

Hitt NP, Angermeier PL. 2011. Fish community and bioassessment responses to stream network position. $J N$ Am Benthol Soc 30: 296-309.

Huet M. 1959. Profiles and biology of western European streams as related to fisheries management. Trans Am Fish Soc 88: $155-163$.

Ibrahimi H, Kučinić M, Gashi A, Grapci-Kotori L. 2014. Trichoptera biodiversity of the Aegean and Adriatic Sea basins in the Republic of Kosovo. J Insect Sci 14: 1-8.

IMBRIW. 2013. Inland Waters Fish Monitoring Operations Manual: Electrofishing Health And Safety / HCMR Rapid Fish Sampling Protocol (Version 1). Athens, Greece: Institute of Marine Biological Resources and Inland Waters (IMBRIW) of the Hellenic Center for Marine Research (HCMR), $79 \mathrm{p}$.

Jelić D, Špelić I, Žutinić P. 2016. Introduced species community overdominates endemic ichthyofauna of high Lika plateau (central Croatia) over a 100 year period. Acta Zool Acad Sci Hung 62: 191-216.

Kalous L, Rylková K, Bohlen J, Šanda R, Petrtýl M. 2013. New mtDNA data reveal a wide distribution of the Japanese ginbuna (Carassius langsdorfii; Cyprinidae) in Europe. J Fish Biol 82: 703-707.

Knezevic B. 1981. Fishes of Lake Skadar. In: The biota and limnology of Lake Skadar (Karaman GS, Beeton AM, Eds). Titograd, pp. 311-315.

Kottelat M, Freyhof J. 2007. Handbook of European freshwater fishes. Kottelat, Cornol, and Freyhof, Berlin, 646 p.

Koutsikos N, Zogaris S, Vardakas L, Tachos V, Kalogianni E, Šanda R, Chatzinikolaou Y, Giakoumi S, Economidis PS, Economou AN. 2012. Recent contributions to the distribution of the freshwater ichthyofauna in Greece. Medit Mar Sci 13: 268-277.

Koutsikos N, Zogaris S, Vardakas L, Kalantzi O, Dimitriou E, Economou NA. 2019a. Tracking non-indigenous fishes in lotic ecosystems: Invasive patterns at different spatial scales in Greece. Sci Total Environ 659: 384-400.

Koutsikos N, Vardakas L, Zogaris S, Perdikaris C, Kalantzi O, Economou NA. 2019b. Does rainbow trout justify its high rank among alien invasive species? Insights from a nationwide survey in Greece. Aquatic Conserv: Mar Freshw Ecosyst 2019: 1-15.

Leese F, Bouchez A, Abarenkov K, Altermatt F, Borja Á, Bruce K, Ekrem T, Čiampor JrF, Čiamporová-ZatoviČová Z, Costa FO, Duarte S, Elbrecht V, Fontaneto D, Franc A, Geiger MF, Hering D, Kahlert M, Stroil BK, Kelly M, Keskin E, Liska I, Mergen P, Meissner K, Pawlowski J, Penev L, Reyjol Y, Rotter A, Steinke D, van der Wal B, Vitecek S, Zimmermann J, Weigand AM. 2018. Why we need sustainable networks bridging countries, disciplines, cultures and generations for aquatic biomonitoring 2.0: a perspective derived from the DNAquaNet COST action. Adv Ecol Res 58: 63-99.

Leroy B, Dias MS, Giraud E, Hugueny B, Jézéquel C, Leprieur F, Oberdorff T, Tedesco PA. 2019. Global biogeographical regions of freshwater fish species. J Biogeogr 46: 2407-2419.

Marešová E, Delić A, Kostov V, Marić S, Šanda R. 2011. Genetic diversity of Sabanejewia balcanica in the West Balkan and its comparison with other regions. Folia Zool 60: 332-339.

Marková S, Šanda R, Crivelli A, Shumka S, Wilson IF., Vukić J, Berrebi P, Kotlík P. 2010. Nuclear and mitochondrial DNA sequence data reveal the evolutionary history of Barbus (Cyprinidae) in the ancient lake systems of the Balkans. Mol Phylogenet Evol 55: 488-500. 
Matthews WJ. 1998. Patterns in freshwater fish ecology. Norwell USA: Chapman \& Hall/Kluwer Academic Publishers, 756 p.

Mendel J, Lusk S, Vasil'eva ED, Vasil'ev VP, Lusková V, Erk'akan F, Ruchin A, Koščo J, Vetešník L, Halačka K, Šanda R, Pashkov AN, et Reshetnikov SI. 2008. Molecular phylogeny of the genus Gobio Cuvier, 1816 (Teleostei: Cyprinidae) and its contribution to taxonomy. Mol Phylogenet Evol 47: 1061-1075.

Milošević D, Talevski T. 2015. Conservation status of native species in natural lakes of Drim system (Prespa, Ohrid and Skadar Lake) and dangers of commercial fishing. Bulg J Agric Sci 21: 61-67.

Palandačić A, Bravničar J, Zupančič P, Šanda R, Snoj A. 2015. Molecular data suggest a multispecies complex of Phoxinus (Cyprinidae) in the Western Balkan Peninsula. Mol Phyl Evol 92: 118-123.

Palandačić A, Naseka A, Ramler D, Ahnelt H. 2017. Contrasting morphology with molecular data: an approach to revision of species complexes based on the example of European Phoxinus (Cyprinidae). BMC Evol Biol 17: 184.

Perdices A, Bohlen J, Doadrio I. 2008. The molecular diversity of Adriatic spined loaches (Teleostei, Cobitidae). Mol Phyl Evol 46: 382-390.

Perea S, Vukić J, Šanda R, Doadrio I. 2016. Ancient mitochondrial capture as factor promoting mitonuclear discordance in freshwater fishes: a case study in the genus Squalius (Actinopterygii, Cyprinidae) in Greece. PLOS ONE 11: e0166292.

Piria M, Simonović P, Nikolić V, Ristovska M, Apostolou A, Adrović A, Povž M, Zanella D, Mrdak D, Milošević D, Vardakas L, Koutsikos N, Kalogianni E, Gregori A, Kostov V, Škrijelj R, Korro K, Bakiu R, Tarkan AS, Joy MK. 2018. Alien freshwater fish species in the Balkans - vectors and pathways of introduction. Fish Fish 19: 138-169.

Rakaj N. 1995. Iktiofauna e Shqiperise (Ichthyofauna of Albania). Tirana: Shtëpia Botuese "Libri Universitar".

R Development Core Team, 2017. R: A language and environment for statistical computing. Vienna, Austria. R Foundation for Statistical Computing. Available at: http://www.R-project.org/

Reid AJ, Carlson AK, Creed IF, Eliason EJ, Gell PA, Johnson PTJ, Kidd KA, MacCormack TJ, Olden JD, Ormerod SJ, Smol JP, Taylor WW, Tockner K, Vermaire JC, Dudgeon D, Cooke SJ. 2019. Emerging threats and persistent conservation challenges for freshwater biodiversity. Biol Rev 94: 849-873.

Šanda R, Vukić J, Choleva L, Kř́žek J, Šedivá A, Shumka S, Wilson IF. 2008. Distribution of loach fishes (Cobitidae, Nemacheilidae) in Albania, with genetic analysis of populations of Cobitis ohridana. Folia Zool 57: 42-50.

Sanders RE, Miltner RJ, Yoder CO, Rankin ET. 1999. The use of external deformities, erosion, lesions, and tumors (DELT anomalies) in fish assemblages for characterizing aquatic resources: a case study of seven Ohio streams. In T.P. Simon (Ed.), Assessing the sustainability and biological integrity of water resources using fish communities 225-246. Florida: CRC.

Schinegger R, Trautwein C, Melcher A, Schmutz S. 2012. Multiple human pressures and their spatial patterns in European running waters. Water Environ J 26: 261-273.

Schmutz S, Kaufmann M, Vogel B, Jungwirth M, Muhar S. 2000. A multi-level concept for fish-based, river-type-specific assessment of ecological integrity. In: Jungwirth M, Muhar S, Schmutz S. (eds.), Assessing the Ecological Integrity of Running Waters, Kluwer Academic Publishers, Dordrecht, 279-289.

Schönhuth S, Vukić J, Šanda R, Yang L, Mayden RL. 2018. Phylogenetic relationships and classification of the Holarctic family Leuciscidae (Cypriniformes: Cyprinoidei). Mol Phyl Evol 127: 781-799.
Šedivá A, Janko K, Šlechtová V, Kotlík P, Simonović P, Delić A, Vassilev M. 2008. Around or across the Carpathians: colonization model of the Danube basin inferred from genetic diversfications of stone loach (Barbatula barbatula) populations. Mol Ecol 17: 1277-1292.

Shumka S, Paparisto A, Grazhdani S. 2008. Identification of non-native freshwater fishes in Albania and assessment of their potential threats to the national biological freshwater diversity. Balwois 2008-Ohrid, Republic of Macedonia - 21, 31 May 2008.

Simonović P. 2001. Ribe Srbije (Fish of Serbia). Belgrade, Serbia: NNK International (in Serbian).

Skoulikidis N, Economou AN, Gritzalis KC, Zogaris S. 2009. Rivers of the Balkans, In: Rivers of Europe (Ed. Tockner K, Uehlinger U, Robinson CT.). pp. 421-466. Amsterdam: Elsevier Academic Press.

Šorić VM. 1990. Ichthyofauna of the Ohrid-Drim-Skadar system. Ichthyologia 22: 31-43.

Šrić V. 1992. The second contribution to the knowledge of the Metohija potamologic systém. Ichthyologia 24: 33-42.

Sousa-Santos C, Matono P, Da Silva J, Ilhéu M. 2018. Evaluation of potential hybridization between native fish and the invasive bleak, Alburnus alburnus (Actinopterygii: Cyprinidae). Acta Ichthyol Piscat 48: 109-122.

Sousa-Santos C, Jesus TF, Fernandes C, Robalo JI, Coelho MM. 2019. Fish diversification at the pace of geomorphological changes: evolutionary history of western Iberian Leuciscinae (Teleostei: Leuciscidae) inferred from multilocus sequence data. Mol Phylogenet Evol 133: 265-285.

Spirkovski Z, Palluqi A, Flloko T, Miraku E, Kapedani D, Ilik-Boeva T, Talevski B, Trajcevski D, Ritterbusch U, Brämick M, Pietrock und R. Peveling, 2017. Fish and Fisheries Lake Ohrid Implementing the EU Water Framework Directive in SouthEastern Europe. Deutsche Gesellschaft für Internationale Zusammenarbeit (GIZ), Bonn, Eschborn. Pegi Sh.p.k. Book Publisher, Tirana.

Stierandová S, Vukić J, Vasil'eva ED, Zogaris S, Shumka S, Halačka K, Vetešník L, Švátora M, Nowak M, Stefanov T, Koščo J. 2016. A multilocus assessment of nuclear and mitochondrial sequence data elucidates phylogenetic relationships among European spirlins (Alburnoides, Cyprinidae). Mol Phylogenet Evol 94: 479-491.

Sutela T, Vehanen T, Jounela P. 2010. Response of fish assemblages to water quality in boreal rivers. Hydrobiologia 641: 1-10.

Ter Braak CJ, Smilauer P. 2002. CANOCO reference manual and CanoDraw for Windows user's guide: software for canonical community ordination (version 4.5). www.canoco.com.

Townsend CR, Doledec S, Norris R, Peacock K, Arbuckle C, 2003. The influence of scale and geography on relationships between stream community composition and landscape variables: description and prediction. Freshw Biol 48: 768-85.

Tutman P, Buj I, Ćaleta M, Hamzić A, Korjenić E, Adrović A, Glamuzina B. 2017. Status and distribution of spined loaches (Cobitidae) and stone loaches (Nemacheilidae) in Bosnia and Herzegovina. Folia Zool 66: 211-226.

Vavalidis T, Zogaris S, Economou AN, Kallimanis AS, Bobori DC. 2019. Changes in Fish Taxonomy Affect Freshwater Biogeographical Regionalisations: Insights from Greece. Water 11: 1743.

Vila-Gispert A, Garcia-Berthou E, Moreno-Amich R, 2002. Fish zonation in a Mediterranean stream: Effects of human disturbances. Aquat Sci 64: 163-170.

Vlami V, Zogaris S, Djuma H, Kokkoris IP, Kehayias G, Dimopoulos P. 2019. A Field Method for Landscape Conservation Surveying: The Landscape Assessment Protocol (LAP). Sustainability 11. 
Vucić M, Jelić D, Žutinić P, Grandjean F, Jelić M. 2018. Distribution of Eurasian minnows (Phoxinus: Cypriniformes) in the Western Balkans. Knowl Manag Aquat Ecosyst 419: 11.

Vukić J, Eliášová K, Marić D, Šanda R. 2019. Occurrence of alien spirlin (Alburnoides sp.) in the Neretva river basin. Knowl Manag Aquat Ecosyst 420: 15.

Waschak M. 2012. Water Pollution by Solid Waste in Kosovo. Available from https://wiki.rit.edu/display/0508484022122/Final +Paper, +Water+Pollution+by+Solid+Waste+in+Kosovo

Wenke M. 2017. On the distribution of fish species in Erenik River and its tributaries (Western Kosovo). Bachelor's thesis report (Supervised by Gregor Schmitz). University of Konstanz, Faculty of Sciences Department of Biology.

Wiens JA. 2002. Riverine landscapes: taking landscape ecology into the water. Freshw Biol 47: 501-515.

Wood PJ, Armitage PD. 1997. Silt and siltation in a lotic environment. Ecol Envir 21: 203-217.

WWF/TNC 2019. Freshwater Ecoregions Of The World: A global biogeographical regionalization of the Earth's freshwater biodiversity. Southeast Adriatic Drainages (Author: Jennifer Hales); https://www.feow.org/ecoregions/details/420

Zajicek P, Wolter C. 2018. The gain of additional sampling methods for the fish-based assessment of large rivers. Fish Res 197: 15-24.

Zajicek P, Radinger J, Wolter C. 2018. Disentangling multiple pressures on fish assemblages in large rivers. Sci Total Environ 627: $1093-1105$

Zogaris S, Economou AN, Dimopoulos P. 2009. Ecoregions in the southern Balkans: should they be revised? Environ Manag 43: 682-697.

Zogaris S, Tachos V, Economou AN, Chatzinikolaou Y, Koutsikos N, Schmutz S. 2018. A model-based fish bioassessment index for Eastern Mediterranean rivers: application in a biogeographically diverse area. Sci Total Environ 622: 676-689.

Zupančič P, Marić D, Naseka AM, Bogutskaya NG. 2010. Squalius platyceps, a new species of fish (Actinopterygii: Cyprinidae) from the Skadar Lake basin. Zoosystematica Rossica 19: $154-167$.

Cite this article as: Grapci-Kotori L, Vavalidis T, Zogaris D, Šanda R, Vukić J, Geci D, Ibrahimi H, Bilalli A, Zogaris S. 2020. Fish distribution patterns in the White Drin (Drini i Bardhë) river, Kosovo. Knowl. Manag. Aquat. Ecosyst., 421, 29. 